\title{
Restoration Notes
}

Restoration Notes have been a distinguishing feature of Ecological Restoration for more than 25 years. This section is geared towards introducing innovative research, tools, technologies, programs, and ideas, as well as providing short-term research results and updates on ongoing efforts. Please direct submissions and inquiries to the editorial staff (mingram@ wisc.edu and cmreyes@wisc.edu).

\section{Viability of Warm-Season Grass Seed from Grazed and Ungrazed Prairies (Illinois)}

Daniel G. Wenny (Illinois Natural History Survey, Lost Mound Field Station, 3159 Crim Dr, Savanna, IL 61074, dwenny@inhs.uiuc.edu) and RandyW. Nj̈boer (Illinois Endangered Species Protection Board, 3159 Crim Dr, Savanna, IL 61074, rnyboer@inhs.uiuc.edu)

The choice of seed collection sites for reconstruction and restoration of native plant communities is critical to the success of restoration efforts. Local site variations and past land uses, such as grazing, can greatly influence the abundance and viability of seed, and thus the success of the restoration.

Despite the vast number of studies on the effects of cattle grazing on plants, little information is available on the impacts of intensive grazing on seed production or seed viability of forage plants. The few studies on this subject indicate that grazing, especially in the absence of fire, can result in lower seed production or lower seed viability of grasses (Hartnett 1989, Dyer 2002). Because defoliation can decrease plant fitness via reductions in plant vigor, flowering, and seed production (Buwai and Trlica 1977, Marquis 1984), intensive livestock grazing may affect seed production of forage plants (Hartnett 1989). Plants in intensively grazed areas may need time (one or more growing seasons) to recover and invest energy in vegetative growth before they can devote energy to flowering and seed production (Buwai and Trlica 1977, Ansley et al. 2006, Lyons and Hanselka 2001).

Plant vegetative responses to grazing have been studied extensively (Diaz et al. 2006). Weaver (1954) classified big bluestem (Andropogon gerardii), Indian grass (Sorghastrum nutans), and little bluestem (Schizachyrium scoparium) among the species that decrease in response to intensive grazing. Of these three species, he considered big bluestem the most preferred and little bluestem the least preferred by cattle. He noted that little bluestem did not withstand grazing as well as big bluestem (Weaver 1954, 277) because little bluestem is less capable of rhizomatous growth than the other two species.

Ecological Restoration Vol. 26, No. 1, 2008

ISSN 1522-4740 E-ISSN 1543-4079

(02008 by the Board of Regents of the University of Wisconsin System.
In several small-scale prairie plantings we are involved with, germination and establishment of little bluestem, the primary warm season grass of sand prairie, appeared poor. Other studies also report poor establishment of little bluestem (Meyer and Gaynor 2002) and lower germination rates of little bluestem than big bluestem or Indian grass (Blake 1935), but the reasons for such poor establishment have not been determined. Because many of our seed collection sites had been intensively grazed but not burned for decades prior to our collections (Robertson et al. 1997), we hypothesized that such long-term intensive grazing led to lower seed viability through decreased plant vigor.

We collected seeds of three grass species in October 2003 from nine sites that had been intensively grazed by cattle until September 1999 and from seven sites that had not been grazed for at least 20 years. All sites were remnant sand prairie under similar management regimes and the plants were local ecotypes. We collected seed by hand into paper bags. Each sample contained a volume of approximately $10 \mathrm{~cm}^{3}$ seeds from multiple plants. The collection sites were in Whiteside (1 site), Carroll (8 sites), and Jo Daviess Counties (7 sites) in northwestern Illinois. Two of the ungrazed sites were state natural areas that had been grazed up until preserve establishment in the early 1970 s. The remaining ungrazed and all grazed sites were all at the former Savanna Army Depot, a 5,200-ha military base that closed in March 2000. The army used intensive cattle grazing to minimize the risk of wildfire, but cattle were excluded by fences from some ecologically sensitive areas that we used for some of the ungrazed sites. All sites are within $48 \mathrm{~km}$ of each other on two sand terraces between the Mississippi River and wooded bluffs to the east. The sites constitute remnants of two 20,000-ha sand prairies formed after Wisconsinian glacial retreat approximately 10,000 years ago (Robertson et al. 1997). We collected all three species from all seven ungrazed sites. The three species did not all occur at all nine grazed sites; we collected six big bluestem, eight Indian grass, and nine little bluestem samples from grazed prairie sites.

We collected samples between October 1 and 10, 2003, and sent them to the Illinois Department of Agriculture seed lab. Bags were labeled only with species and sample number. The seed lab planted 50 to 200 seeds from each sample with no pre treatment (Shirley 1994, Heon and Larson 1999). Our samples of little bluestem had many 
empty seeds despite the appearance of fully formed awns so the seed lab could not always plant 200 seeds from each sample. Data are reported as the proportion that germinated and were arcsine transformed for analysis. We analyzed the data with one-way ANOVA and Bonferroniadjusted pairwise comparisons.

Seed viability varied considerably among samples ranging from a low of $18 \%$ to a high of $93 \%$ (Figure 1). Germination among the three species was significantly different $\left(F_{2,41}=20.49, p<0.001\right)$ with little bluestem viability significantly lower than the other two species (Bonferroni post-hoc tests, $p<0.001)$. This difference among species was due to significantly lower viability of little bluestem from grazed sites than big bluestem or Indian grass from any sites $\left(F_{5,38}=8.89, p<0.001\right.$, Bonferroni tests, $p<0.001)$. However, within each species, germination did not differ between the grazed and ungrazed prairies (Bonferroni tests, $p>0.05$; Figure 1).

Genetic differences among populations are a common feature of native plants, as work by Phan and Smith (2000) and Gustafson et al. (2004) demonstrates. These studies, in keeping with our own research, underscore the high variability in seed viability among local populations, and illustrate the importance of using local ecotypes in restorations. This in turn points to the need for evaluating seed viability of local populations in order to make appropriate seed mixes for restorations.

Our results also indicate that little bluestem has intrinsically lower germination rates than big bluestem or Indian grass in our area. Therefore, we need to increase the amount of little bluestem seed in our mixes to account for the lower viability. More information is needed on the variation in viability from year to year and across a wider geographic area. Seed testing is widely available (Elias et al. 2006, Gutormson 2005) and can be helpful if used on a regular basis. Restoration efforts can be made more efficient if seed viability is tested before planting, or if time allows, before extensive collecting. If incorporated into regular restoration practices the information on seed viability and variation will be valuable in its own right.

\section{Acknowledgments}

Thanks to Grace Storch and Judy Eaton for help collecting seeds. Funding from the Illinois Natural History Survey is gratefully acknowledged. Wendy Gibbons and the editors provided valuable comments on the manuscript.

\section{References}

Ansley, R.J., M.J. Castellano and W.E. Pinchak. 2006. Sideoats grama growth responses to seasonal fires and clipping. Rangeland Ecology \& Management 59:258-266.

Blake, A.K. 1935. Viability and germination of seeds and early life history of prairie plants. Ecological Monographs 5:405-460.

Buwai, M. and M.J. Trlica. 1977. Multiple defoliation effects on

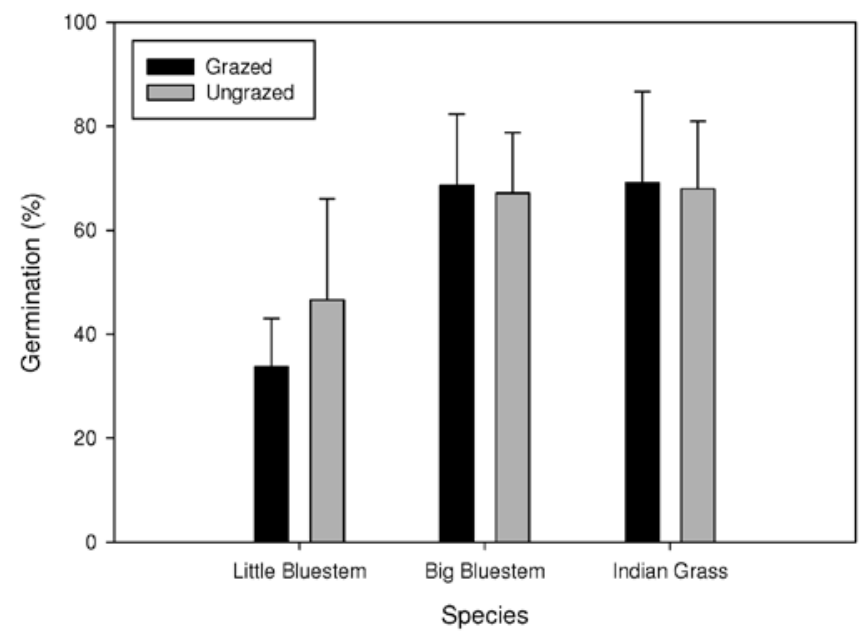

Figure 1. Mean ( \pm SD) percent germination of little bluestem (Schizachyrium scoparium), big bluestem (Andropogon gerardii), and Indian grass (Sorghastrum nutans) from grazed and ungrazed sand prairies in northwestern Illinois. Germination within species averaged $67 \% \pm 12 \%$ for big bluestem, $68 \% \pm 15 \%$ for Indian grass, and $39 \% \pm 15 \%$ for little bluestem.

herbage yield, vigor, and total nonstructural carbohydrates of five range species. Journal of Range Management 30:164-171.

Diaz, S., S. Lavorel, S. McIntyre, V. Falczuk, F. Casanoves, D.G. Milchunas, C. Skarpe, G. Rusch, M. Sternberg, I. Noy-Meir, J. Landsberg, W. Zhang, H. Clark and B.D. Campbell. 2006. Plant trait responses to grazing-a global synthesis. Global Change Biology 12:1-29.

Dyer, A.R. 2002. Burning and grazing management in a California grassland: Effect on bunchgrass seed viability. Restoration Ecology 10:107-111.

Elias, S., A. Garay, L. Schweitzer and S. Hanning. 2006. Seed quality testing of native species. Native Plants Journal 6:15-19.

Gustafson, D.J., D.J. Gibson and D.L. Nickrent. 2004. Conservation genetics of two co-dominant grass species in an endangered grassland ecosystem. Journal of Applied Ecology 41:389-397.

Gutormson, T. 2005. Tetrazolium, germination, dormancy and fungal interactions. Seed World July/August:10-12.

Hartnett, D.C. 1989. Density- and growth stage-dependent responses to defoliation in two rhizomatous grasses. Oecologia 80:414-420.

Heon, A. and A. Larson. 1999. Begin with a Seed: The Riveredge Guide to Growing Wisconsin Prairie Plants. Newburg, WI: Riveredge Nature Center.

Lyons, R.K. and C.W. Hanselka. 2001. Grazing and browsing: How plants are affected. Texas A \& M University Cooperative Extension B-6114. http://rangeweb.tamu.edu/extension/ rangedetect/b6114_grz\&brw.pdf.

Marquis, R.J. 1984. Leaf herbivores decrease fitness of a tropical plant. Science 226:537-539.

Meyer, M.H. and V.A. Gaynor. 2002. Effect of seeding date on establishment of native grasses. Native Plants Journal 3:132-138.

Phan, A.T. and S.R. Smith. 2000. Seed yield variation in blue grama and little bluestem plant collections in southern Manitoba, Canada. Crop Science 40:555-561.

Robertson, K.R., L.R. Phillippe, G.A. Levin and M.J. Moore. 1997. Delineation of natural communities, a checklist of vascular plants, and new locations for rare plants at the Savanna Army 
Depot, Carroll and Jo Daviess Counties, Illinois. Illinois Natural History Survey Technical Report 1997 (2).

Shirley, S. 1994. Restoring the Tallgrass Prairie: An Illustrated Manual for Iowa and the Upper Midwest. Iowa City: University of Iowa Press.

Weaver, J.E. 1954. North American Prairie. Lincoln, NE: Johnsen Publishing Company.

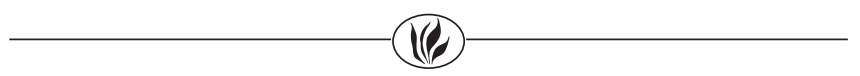

\section{Artichoke as an Ecological Resource and Its Utility as a Precursor to Restoration (California)}

Peter A. Bowler (Dept of Ecology and Evolutionary Biology, University of California, Irvine, CA 92697-2525, pabowler@uci.edu)

\section{"Kill_ creating a vacancy without nominating a successor."}

\section{—Ambrose Bierce, Devil's Dictionary}

Native California grassland has been reduced to less than $1 \%$ of its historic extent, and estimates of coastal sage scrub loss to development or habitat conversion vary from 85 to $95 \%$. These communities continue to diminish and have been damaged by historic grazing, altered fire cycles, isolation of remaining fragments, encroachment by nonnative species, perhaps aerial nitrogen deposition, and other anthropogenic disturbances. Globe artichoke (Cynara cardunculus, Asteraceae) is one of the problematic invaders that have become widespread in southern California grassland and, to a lesser extent, coastal sage scrub habitat.

Introduced in the nineteenth century, likely as a food plant, artichoke is a perennial that reproduces by winddispersed seeds borne in attractive purple, thistle-like flower heads (the "artichoke"). A fibrous taproot up to $1.5 \mathrm{~m}$ long allows the plant to retain leaves year-round after the primary inflorescence senesces, although in xeric sites the whole plant may die back to the ground after flowering. Adults vary greatly in size, but can attain heights of 2.5 $\mathrm{m}$ and cover a circle measuring $1.5 \mathrm{~m}$ diameter. Once established, globe artichoke is difficult to eradicate with means other than herbicides, and it often forms large, nearly monotypic stands.

Dense artichoke stands form their own species-poor plant subcommunity, often comprised of, besides artichoke, non-native annual grasses, black mustard (Brassica nigra), and very few native taxa. It seems to represent an advanced seral stage in disturbed areas with little apparent change over long periods of time. Globe artichoke benefits some native animals, both directly and in a facultative sense. Many pollinators visit the flowers, but insect herbivory is limited and few animals actually eat the plant.

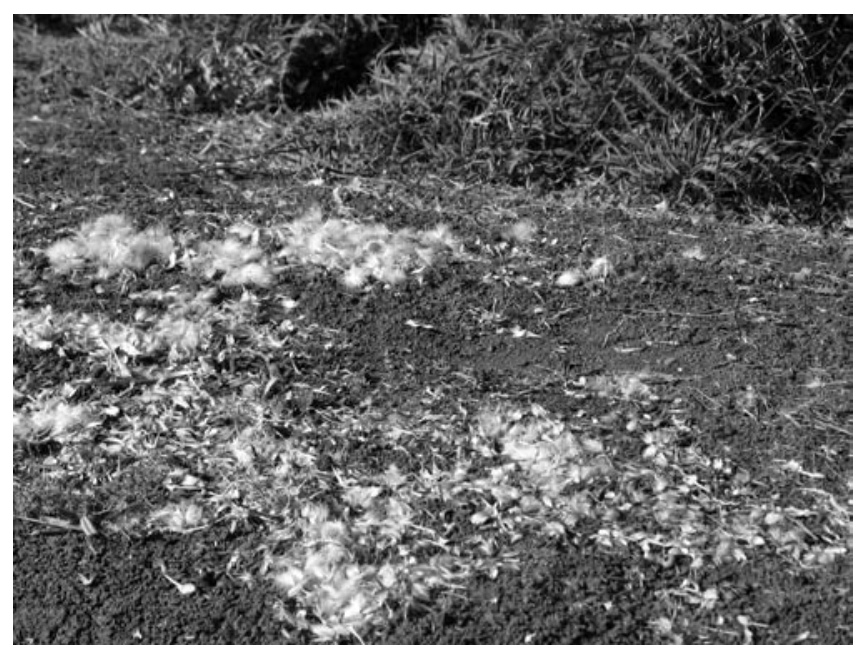

Figure 1. Dissected flower heads (foreground) provide evidence of groundsquirrels (Otospermophilus [= Spermophilus] beecheyi) foraging on globe artichokes (Cynara cardunculus) in the University of California Natural Reserve System's San Joaquin Freshwater Marsh Reserve. Photo by Peter A. Bowler

California ground squirrels (Otospermophilus $[=$ Spermophilus] beecheyi) and many bird species forage upon its seeds (Figure 1). It also provides meter-high perch sites in otherwise perch-poor grasslands. Costa's hummingbirds (Calypte costae), Anna's hummingbirds (C. anna), and black-chinned hummingbirds (Archilochus alexandri) were reported to have an estimated $24 \%$ nesting success (of 59 active nests) on artichoke branches and leaves, a success rate within the range reported for these species elsewhere (Keber and Banack 2006). Thus, even an artichoke-dominated site is "habitat," with its own limited food web and resident or foraging group of wildlife.

Sites dominated by artichoke are often simplistically written off as being ecologically worthless, but as intact native habitat dwindles, the value of disturbed areas as buffers and biological corridors gradually increases, as does their value were they restored, even though adequate legal protection for these damaged habitats is still lacking (Bowler 1992). Thus, unfortunately, disturbed areas frequently are viewed as not worthy of ecologic consideration, leaving them open to urban or other kinds of development. This is an anachronistic view, in a sense rewarding overgrazing and poor ecological practices in the past by guaranteeing anthropogenic succession of use in the future-ultimately, hardscaped development. The potential ecological worth of these sites were they restored is usually completely overlooked-like a horse with a broken leg, their fate is sealed.

Moreover, artichoke stands are readily revegetated with native plants, since they rarely contain a large seed bank of exotic taxa other than artichoke, and they form a halo into which containerized native plants can be easily transplanted as part of an assembly method of coastal sage scrub restoration. Seeding also works well as a more successional approach, though if glyphosate was used as an herbicide 
to eradicate artichoke, seeds should not be introduced for at least a month and a half.

As an example, a 1.2-ha upland restoration was remarkably successful adjacent to the University of California Natural Reserve System's San Joaquin Marsh Reserve (Orange County, CA) (see Bowler 2000). Several large stands of artichoke were eliminated and planted with sage scrub container plants, primarily coastal sagebrush (Artemisia californica), black sage (Salvia mellifera), and buckwheat (Eriogonum fasciculatum). These sites, particularly along a San Diego Creek levee with a fill substrate, have formed nearly closed canopy stands of native shrubs with little invasion by non-natives. Even before transplants were well established, very little invasion occurred at sites where artichoke was dominant before eradication. This conversion from artichoke to a more species-rich and native-based situation, however, displaced ground squirrels that used the artichoke extensively.

Although cathartic, large-scale artichoke eradication without full-fledged efforts to replace it with native species merely shifts succession to ecologies that are much more difficult to remediate. The Nature Reserve of Orange County has expended substantial funds since 1994 using Roundup (glyphosate) and other herbicides in an attempt to reduce artichoke on the more than 1,600 ha of infested lands enrolled in the Natural Communities Conservation Program. In a review of artichoke control efforts in Orange County, California, Suding (2007) found that the perennial bunchgrass purple needlegrass (Nassella pulchra) was one of the few native species that increased following artichoke eradication, while the non-native black mustard and ripgut brome (Bromus diandrus) greatly expanded and dominated many sites. If artichoke can be contained, it is useful to not completely eradicate it from a site until it is to be replaced with native vegetation, thus preventing the undesirable trajectory towards an exotic annual grassland or black mustard-dominated situation.

Introducing artichoke into mustard or exotic grass stands as a stepping stone to restoration is an intriguing concept, but would be politically challenging, given the vigorous decade-long campaign to herbicide artichoke at significant cost. To pursue such an approach would require data demonstrating that subsequent sage scrub establishment was more rapid with higher survivorship at former artichoke inhabited sites - and it would require keeping artichoke in check, perhaps by removing flower heads prior to seed set. Using exotics like artichoke to manipulate succession at highly disturbed sites to favor the restoration of native habitats is an unexplored approach that deserves cautious consideration. Opportunistically taking advantage of extant artichoke as a relatively easily killed steppingstone to restoration is the more conservative and readily adopted path.

\section{Acknowledgments}

I am grateful to Chris Reyes for excellent suggestions and recommended revisions of this discussion.

\section{References}

Bowler, P.A. 1992. Biodiversity conservation in Europe and North America. II. Shrublands-In defense of disturbed land. Restoration \& Management Notes 10:144-149. 2000. Ecological restoration of coastal sage scrub and its potential role in habitat conservation plans. Environmental Management 26:S85-S96.

Keber, R.J. and S.A. Banack. 2006. The influence of artichoke thistle on hummingbird populations. Poster presented at the 2006 Ecological Society of America Conference, in Memphis, TN, August 10. http://abstracts.co.allenpress.com/pweb/esa2006/ document $/$ ?ID $=61742$.

Suding, K.N. 2007. Measuring the sustainability of artichoke thistle (Cynara cardunculus) control efforts following suspension of control activities in historic southern California rangeland. Final Report to the Nature Reserve of Orange County.

\section{Raising a Ranch from the Dead: 50 Years of Restoration on the Carrizo Valley Ranch (New Mexico)}

Sid Goodloe (Carrizo Valley Ranch) and Charles Curtin (MIT-USGS Science Impact Collaborative, MIT, Dept of Urban Studies Planning, 77 Massachusetts Ave, 9-330, Cambridge, MA 02139, ccurtin@earthlink.net)

The important work of restoration often occurs not as part of vast federally funded projects but on the initiative of individuals who decide to take a creative and adaptive approach to restoration and management on their own lands (e.g., Leopold 1949). Academic literature increasingly recognizes the importance of local and endemic knowledge in the stewardship of natural resources (Berkes et al. 2003, Curtin 2005, forthcoming). The work on the Carrizo Valley ranch in south-central New Mexico over the past 50 years, on which we report here, highlights the dynamic nature of natural systems and the very important role individual land owners can play as restorers of the natural world.

I (Sid Goodloe) purchased the 1,416-ha Carrizo Valley Ranch near Capitan, New Mexico, in 1956. Because I grew up and was educated in Texas, I brought a newcomer's perspective to the management of my ranch and the terrain, plants, and animals. Fifty years ago, Carrizo Valley Ranch had a solid canopy of piñon (Pinus edulis), juniper (Juniperus deppeana), and ponderosa (Pinus ponderosa), with almost no ground cover-conditions with ecological implications for the health of the land. When I was caught in a thunderstorm I was able to see the soil erosion caused 
by a lack of herbaceous ground cover. Every time we had a rain shower, Carrizo Creek ran too thick to drink and too thin to plow. There were also too many young, even-aged trees covering too large an area to be a natural long-term phenomenon. I surmised that the lack of fire had made it possible for these thousands of young trees to survive. The livestock boom after the Civil War had obliterated most of the ground forage that carried fires, and this "fire-drought" was further exacerbated by the U.S. Forest Service's (USFS) increasingly efficient fire suppression policy.

Two other things made it possible for me to come to a conclusion that overgrazing and fire suppression had resulted in a totally different vegetative complex on the ranch. First, Native American petroglyphs nearby showed beaver (Castor canadensis) and fish in a local wash where now there was only an eroding, boulder-strewn ephemeral stream (Figure 1). The second revelation was surveyors' notes from the 1880s indicating a lack of witness trees to mark a property boundary in a place where I now found a solid tree canopy. These revelations provided proof that overgrazing and fire suppression had completely changed the native vegetative complex. I decided to restore that vegetation from dense stands of colonizing piñon, juniper, and ponderosa pine with little or no grass underneath to a more diverse landscape mosaic comprised of ponderosa forest, open stands of mixed tree species, and grasslands.

My first attempt to change the vegetative complex involved chaining 688 ha in the late 1950s. I began by uprooting the piñon and juniper that covered a significant part of the watershed above Carrizo Creek. As soon as that operation was completed, Carrizo Creek became an intermittent stream with substantial pools of water for use by both livestock and wildlife.

Chaining was a popular approach in New Mexico at that time for removing water-hungry plants. It involved one-way chaining and placing livestock on the resulting grass. That, of course, was a big mistake. Chaining once was not enough and the trees soon resprouted and came back. We later learned that chaining should be done in both directions, followed by seeding the disturbed soil with native grasses. Dry matter should be burned a year later and the hotspots subsequently reseeded with native grasses, all the while protecting the areas from grazing. Once we understood this, we began to bulldoze, pile, and then burn the colonizing plants. We were also faced with reinfestation of the rehabilitated areas due to the tremendous seed bank and a continuing deposit of seeds by birds, animals, and wind. Over the next 30 to 40 years we combated this reinfestation using fire, hand grubbing, and the herbicide Pronone (hexazinone). Hand grubbing is still the preferred method of removing invading ponderosa pine, and we have settled on the use of the Pronone pellet to remove the juniper and piñon when fire is not an option. The Natural Resources Conservation Service's cost-share program has been extremely helpful in supporting these restoration efforts.

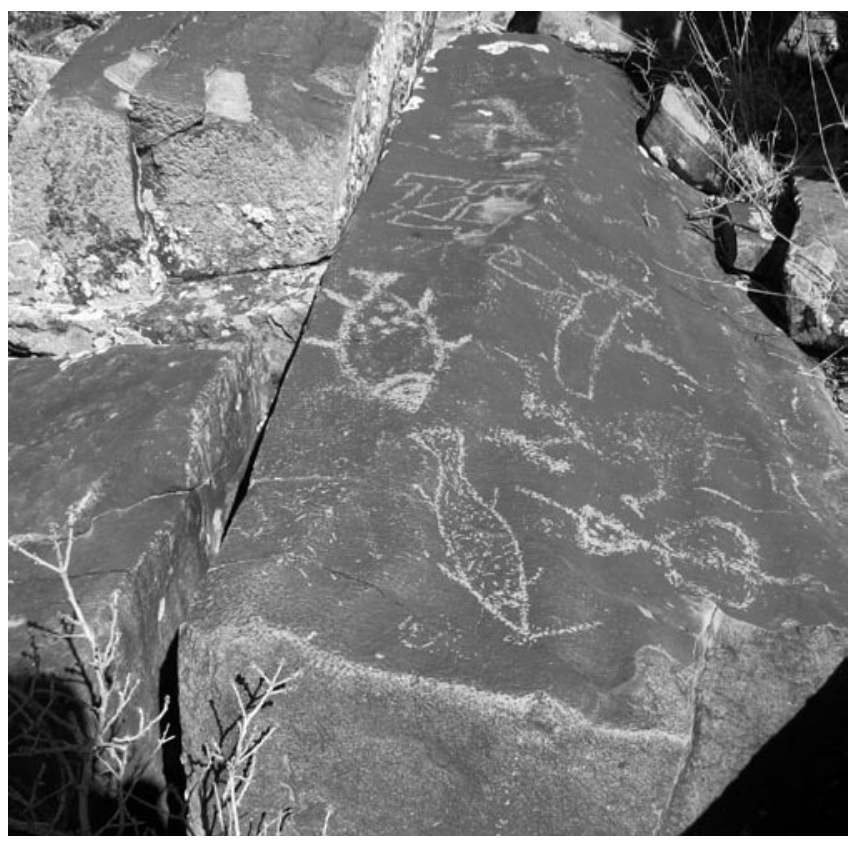

Figure 1. Because Native American petroglyphs in the region depict fish and beaver from 600 years ago, I decided that once I had at least partially slowed the erosion process and made more water available for Carrizo Creek through vegetation management on the watershed, I would reintroduce beaver (Castor canadensis) into the ecosystem. I was able to find beaver, but the New Mexico Department of Game and Fish required sterilization before introduction, and the beaver did not survive the severe shock. If our current drought ends before my life does, I plan to attempt beaver reintroduction again, but it will be from a local area and without sterilization. Photos by Sid Goodloe

Soon after Carrizo Creek became an intermittent stream rather than a stream that ran only after a hard shower, I realized that I needed to utilize the vast amount of silt that was contained in the runoff of the highly eroded National Forest lands above me. The USFS became aware of the silt problem, and that erosion from the National Forest was polluting Carrizo Creek. We teamed up to stabilize the soil and slow the rate of runoff by placing gully plugs every 30 meters and throwing cut brush in the gully to catch soil. The combination of brush and plugs is important because without the stone, the brush washes downstream; without the brush, areas immediately upstream of the plugs fill, water flows over the top of the drop, and eventually undercuts the plug. The USFS originally inserted the plugs at the bottom of the watershed only to find that they washed out, and we realized that treatments had to begin at the top of the watershed and work downstream.

I found that by protecting the riparian area during the growing season and utilizing the silt that came with the large showers on the land above me, I was getting many times the production of forage in those areas than I was getting on the uplands above the riparian zone. I also realized that for economic reasons I needed to make use of that riparian area. I tried flash grazing-putting cattle in the riparian area for a very short period of time during the dormant season. This stimulated, fertilized, and cultivated the plants that grew there. 


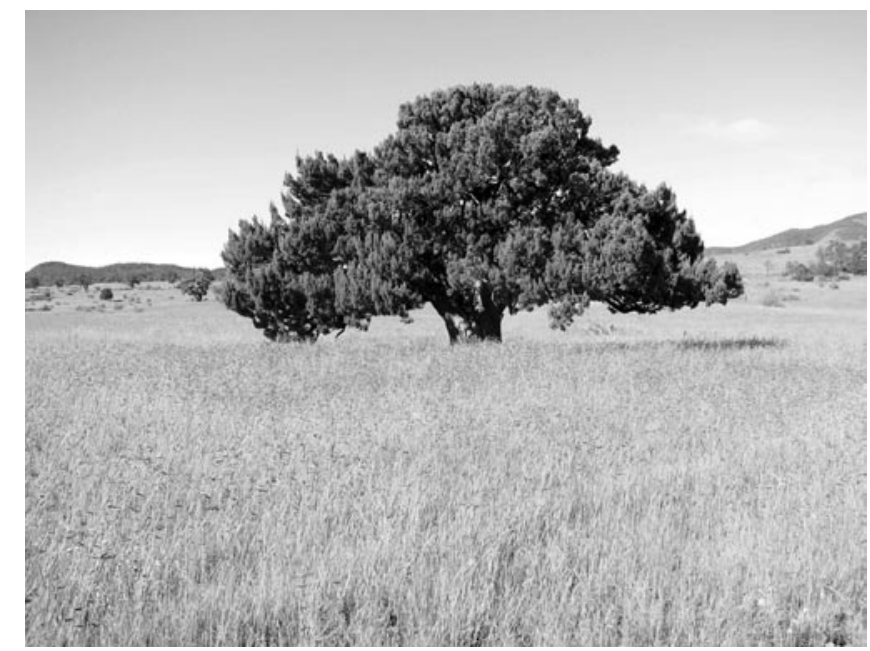

Figure 2. Open grasslands with solitary, relatively large trees are much more typical of the habitat described in surveyor records. The point is not to return our ecosystems to a replica of the 1870s. We now have different climate and soils, as well as the impacts of grazing and fire suppression. Although we can never return to the past, the application of short-term intensive grazing can assist us in replicating the processes that will restore our ecosystems to maximum health. We are striving not only to hand the land down to future generations in better shape than we found it, but also to provide a model for other land managers of what the reinstitution of natural processes can do for both land health and their economic bottom line.

Our improvements produced some unforeseen issues with downstream neighbors who had previously benefited from the heavily silted runoff via a diversion dam that took the water from Carrizo Creek and spread it over a flat area about two miles below our ranch, providing them with excellent, passive fertilization. Our gully plugs have slowed the water moving down the creek, and our efforts at piñon and juniper control have assisted in the percolation of water into the aquifer. As a result, far less silt-infused water flows down Carrizo Creek. We continue to practice good conservation and hope that our efforts will be understood by our neighbors below.

The aesthetic value of an open savanna with a few large trees surrounded by grassland is extremely important, and my family and I feel it will be important to the public in the future (Figure 2). These days we spend most of our time caring for our cattle; cutting, splitting, and delivering firewood; making presentations on watershed rehabilitation; and operating the Southern Rockies Agricultural Land Trust. A conservation easement placed on Carrizo Valley Ranch in 2005 guarantees that fifty years of holistic management and watershed rehabilitation will not be lost under the roofs and pavement of a subdivision. Land stewardship is very important to us and we believe that four principles should be followed in order to be a good land steward: 1) know the history of the ecosystem in which you are operating; 2) manage that ecosystem in a holistic, sustainable manner; 3) share your experience, knowledge, and research with others; and 4) leave a legacy of an operating family ranch rather than land destined to be subdivided.

\section{References}

Berkes, F, J. Colding and C. Folke. 2003. Navigating SocialEcological Systems: Building Resilience for Complexity and Change. Cambridge, UK: Cambridge University Press.

Curtin, C.G. 2005. Complexity, conservation, and culture in the Mexico/US borderlands. Pages 237-258 in B. Child and M.W. Lyman (eds), Natural Resources as Community Assets: Lessons from Two Continents. Monona, WI: Sand County Foundation.

Forthcoming. Knowledge as a community asset. In J. Birkoff, E.F. Dukes and K. Firehock (eds). Community-Based Collaboratives and Natural Resource Management: Putting Knowledge to Work.

Leopold, A. 1949. A Sand County Almanac. Oxford, UK: Oxford University Press.

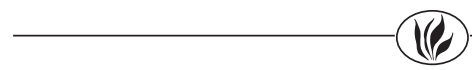

\section{Restoration of Dryland Forests in Latin America: The ReForLan Project}

Adrian C. Newton (School of Conservation Sciences, Bournemouth University, Talbot Campus, Poole, Dorset BH12 5BB, United Kingdom, anewton@bournemouth.ac.uk)

Around the world, arid and semi-arid forests harbor many unique plant and animal species and are also the origin of many important domesticated crop and livestock species. These "drylands" are also home to 35 percent of the world's human population and much of the world's livestock (UNDP 2004). In dryland areas, socioeconomic problems can be severe, extreme poverty is common, and human emigration rates are often high. Restoration and sustainable use of biodiversity is therefore central to livelihood development and poverty alleviation in dryland areas.

A new international collaborative research project, ReForLan, focusing on the restoration of dryland forest landscapes for biodiversity conservation and rural development in Latin America, has received funding from 2007 to 2010 from the European Commission's FP6 International Cooperation and Development (INCO-DEV) program. The collaboration, consisting of ten research teams drawn from Europe and Latin America (Table 1), will be coordinated by Bournemouth University in Dorset, United Kingdom. The project continues a collaborative partnership that has previously examined restoration of moist forest in the region (Newton 2007).

The project has been developed as a response to widespread ecological degradation in dryland areas of Latin America. Dryland soils are particularly prone to erosion as the result of inappropriate tillage, grazing, and use of fire as a land management tool. Open access to resources (both forest and rangeland) and the absence of land security have contributed to the destruction of forest resources in many areas. Relatively little is known, however, about appropriate techniques and approaches for restoring dryland forests in Latin America. These areas have received far less attention 
Table 1. Study areas and institutions participating in ReForLan. Organizations marked with an asterisk will assist with implementation as subcontractors.

\begin{tabular}{|c|c|c|c|c|c|c|}
\hline Country & Study Areas & Forest Type & Features & Elevation & Primary Threats & Cooperators \\
\hline \multirow[t]{3}{*}{ Mexico } & Chiapas & Dry tropical & $\begin{array}{l}\text { Remnants } \\
\text { on slopes }\end{array}$ & $350-1200 \mathrm{~m}$ & $\begin{array}{l}\text { Agriculture } \\
\text { Cattle }\end{array}$ & El Colegio de la Frontera Sur \\
\hline & $\begin{array}{l}\text { Central Veracruz } \\
\text { Paso de Ovejas }\end{array}$ & Dry tropical & $\begin{array}{l}\text { Fragmented } \\
\text { in agricultural } \\
\text { matrix }\end{array}$ & $40-1100 \mathrm{~m}$ & Cattle & $\begin{array}{l}\text { Instituto de Ecologia } \\
\text { Universidad Veracruzana* } \\
\text { Instituto Nacional de } \\
\text { Investigaciones Forestales* }\end{array}$ \\
\hline & $\begin{array}{l}\text { Oaxaca } \\
\text { Mixteca } \\
\text { Oaxaqueña } \\
\text { Central Valley }\end{array}$ & Dry tropical & $\begin{array}{l}\text { Small forest } \\
\text { remnants on } \\
\text { knolls; one } \\
\text { of the most } \\
\text { extreme } \\
\text { cases of } \\
\text { environmental } \\
\text { degradation in } \\
\text { Mexico }\end{array}$ & $\begin{array}{l}1400- \\
3120 \mathrm{~m}\end{array}$ & $\begin{array}{l}\text { Agriculture } \\
\text { Deforestation } \\
\text { Livestock } \\
\text { Soil erosion }\end{array}$ & Instituto Politécnico Nacional \\
\hline \multirow[t]{2}{*}{ Chile } & Central Valley & $\begin{array}{l}\text { Sclerophyllous } \\
\text { Deciduous dry }\end{array}$ & $\begin{array}{l}\text { High } \\
\text { endemism }\end{array}$ & $<500 \mathrm{~m}$ & $\begin{array}{l}\text { Fuelwood harvest } \\
\text { Livestock } \\
\text { Urban expansion }\end{array}$ & $\begin{array}{l}\text { Pontificia Universidad Católica } \\
\text { de Chile Fundación Senda } \\
\text { Darwin* }\end{array}$ \\
\hline & Coastal Range & Sclerophyllous & $\begin{array}{l}\text { High } \\
\text { endemism }\end{array}$ & $<500 \mathrm{~m}$ & $\begin{array}{l}\text { Agriculture } \\
\text { Deforestation } \\
\text { Exotic tree } \\
\text { plantations } \\
\text { Mining } \\
\text { Soil erosion } \\
\text { Urban expansion }\end{array}$ & Universidad Austral de Chile \\
\hline \multirow[t]{2}{*}{ Argentina } & $\begin{array}{l}\text { Northwest } \\
\text { Salta \& Juiuy } \\
\text { Provinces }\end{array}$ & $\begin{array}{l}\text { Subtropical sea- } \\
\text { sonal dry } \\
\text { Andean } \\
\text { premontane } \\
\text { Dry Chaco }\end{array}$ & $\begin{array}{l}\text { The Chaco } \\
\text { is the largest } \\
\text { remaining } \\
\text { area of neo- } \\
\text { tropical dry } \\
\text { forest }\end{array}$ & $350-750 \mathrm{~m}$ & $\begin{array}{l}\text { Agriculture } \\
\text { Deforestation } \\
\text { Selective logging }\end{array}$ & $\begin{array}{l}\text { Fundación Proyungas } \\
\text { Universidad de Tucuman* }\end{array}$ \\
\hline & Southwest & $\begin{array}{l}\text { Forest-steppe } \\
\text { ecotone }\end{array}$ & $\begin{array}{l}\text { Remnant on } \\
\text { slopes and in } \\
\text { ravines }\end{array}$ & 300-1200 m & $\begin{array}{l}\text { Cattle, sheep, } \\
\text { goats } \\
\text { Exotic tree } \\
\text { plantations } \\
\text { Fire }\end{array}$ & $\begin{array}{l}\text { Universidad Nacional del } \\
\text { Comahue }\end{array}$ \\
\hline UK & & & & & & $\begin{array}{l}\text { Bournemouth University } \\
\text { UNEP World Conservation } \\
\text { Monitoring Centre* }\end{array}$ \\
\hline Spain & & & & & & Universidad de Alcala \\
\hline Italy & & & & & & Università degli Studi di Trento \\
\hline
\end{tabular}

from the scientific and conservation community than moist forests, despite the fact that they are now considered to be far more threatened globally (Miles et al. 2006). This lack of attention stems from the traditional view that dryland forests have little or no economic value. This perception is gradually changing as drylands are increasingly being recognized for providing not only water, fuel, and food for local farmers but also a wide range of resources at regional scales. In Chiapas, Mexico, for example, destructive flooding in 1998 was linked to deforestation in central and coastal regions (Richter 2000).

In the past the most common approach to restoration in drylands has been afforestation with exotic tree species, which has often led to negative effects on soil hydrology, fertility, and biodiversity. Success has often been limited by lack of local participation and insufficient knowledge of a complex environment (UNDP 2004). In an attempt to address such problems, ReForLan project activities will focus on restoration of native forest at the landscape scale, using participatory approaches, in seven study areas drawn from Mexico, Chile and Argentina (Tables 1 and 2, Figure 1).

Dryland forest restoration is a long-term process, and the ultimate impact of the project may only become apparent after many years. Positive examples of dryland forest restoration in the region remain few, despite the striking success of the Area de Conservación Guanacaste in Costa Rica (Allen 2001). Our aim is to apply the lessons learned from earlier initiatives to different ecological and socio- 
Table 2. ReForLan goals and planned research activities.

\begin{tabular}{|c|c|c|}
\hline Goal & Activities & Methods \\
\hline Define potential restoration areas & Map historical and current dryland forest distribution & Satellite remote sensing data \\
\hline \multirow[t]{3}{*}{ Prioritize restoration areas } & $\begin{array}{l}\text { Map extent and pattern of forest fragmentation and } \\
\text { degradation }\end{array}$ & Satellite remote sensing data \\
\hline & $\begin{array}{l}\text { Map floral diversity, especially threatened, endemic, or } \\
\text { socioeconomically valuable species }\end{array}$ & Field surveys \\
\hline & $\begin{array}{l}\text { Determine socioeconomic values of natural resources and } \\
\text { land uses }\end{array}$ & Local stakeholder consultations \\
\hline \multirow{4}{*}{$\begin{array}{l}\text { Develop effective restoration and } \\
\text { reclamation techniques }\end{array}$} & Propagate dryland forest species & Field experiments \\
\hline & Identify financial incentives and locally feasible methods & $\begin{array}{l}\text { Socioeconomic surveys } \\
\text { Field experiments }\end{array}$ \\
\hline & Assess socioeconomically and ecologically significant tree species & Intraspecific genetic studies \\
\hline & Test scenarios with land use and climate change parameters & Computer modeling \\
\hline $\begin{array}{l}\text { Develop guidelines and policy } \\
\text { recommendations }\end{array}$ & Synthesize and disseminate research results & Communication tools \\
\hline
\end{tabular}
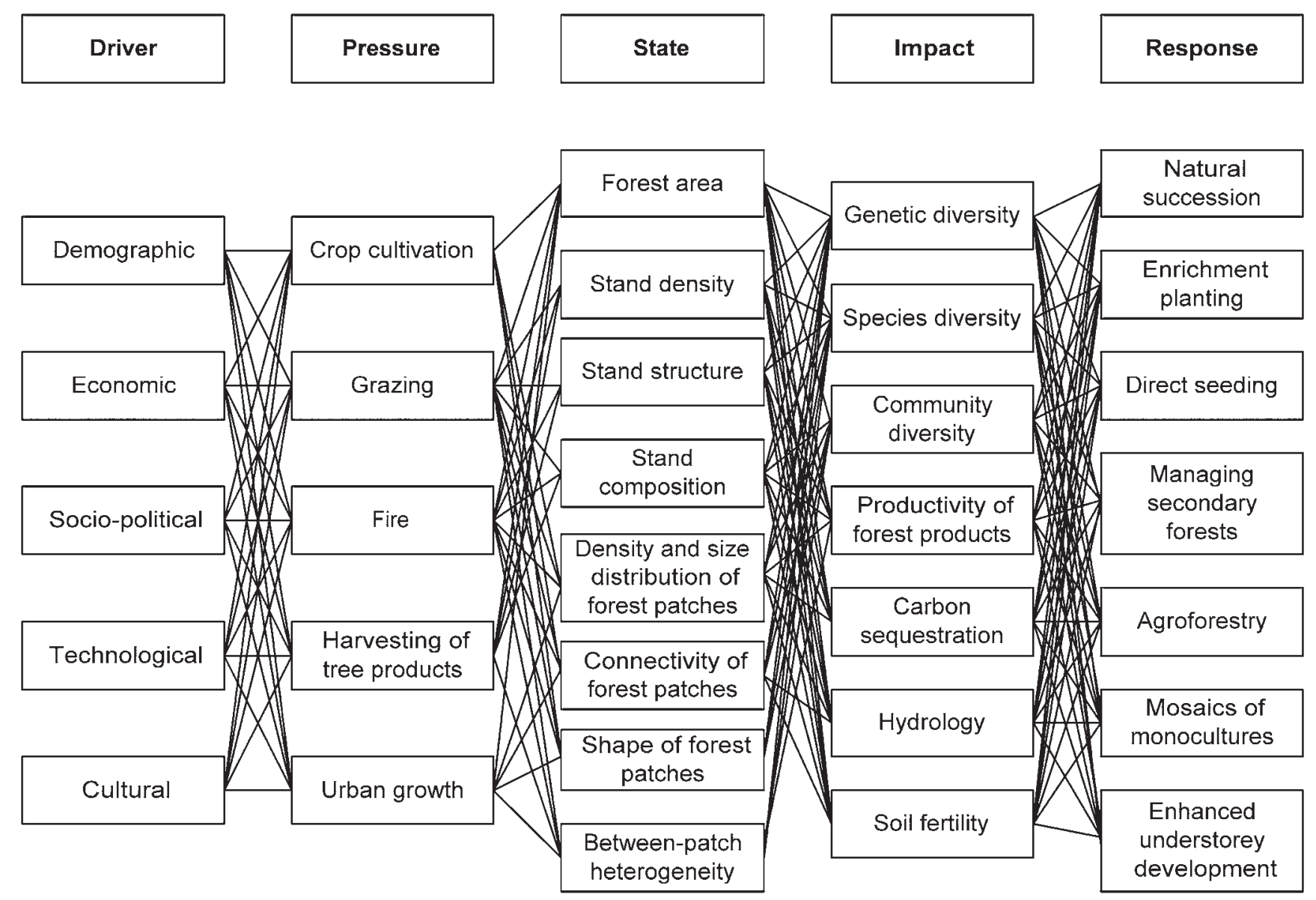

Figure 1. Schematic diagram illustrating the context of ReForLan dryland forest restoration according to a DPSIR framework (EEA 1998): societal Drivers cause various Pressures on the environment that can cause quantitative and qualitative changes in the State of environmental variables. Such changes produce a variety of Impacts on natural resources and the services that they provide. Society has to Respond to these changes in appropriate ways in order to achieve sustainable development. 
economic conditions, including landscapes lying outside protected areas. We will produce restoration strategies and plans, decision support tools, practical guidelines and policy recommendations as well as practical demonstrations of restoration techniques. Another important objective is to catalyze further restoration activity across Latin America. To this end, we will develop a regional network of restoration researchers and practitioners, as recently described by Armesto et al. (2007). We also plan to disseminate our experiences widely through the formal involvement of the UNEP-World Conservation Monitoring Centre and its internet resource Forest Restoration Information Service (FRIS, http://www.unep-wcmc.org/forest/restoration). Further information about the ReForLan project is available at http://reforlan.bournemouth.ac.uk/.

\section{References}

Allen, W.H. 2001. Green Phoenix: Restoring the Tropical Forests of Guanacaste, Costa Rica. New York: Oxford University Press.

Armesto, J.J., S. Bautista, E. Del Val, B. Ferguson, X. García, A. Gaxiola, H. Godinez-Álvarez, G. Gann, F. López-Barrera, R. Manson, M. Núñez-Ávila, C. Ortiz-Arrona, P. Tognetti and G. Williams-Linera. 2007. Towards an ecological restoration network: Reversing land degradation in Latin America. Frontiers in Ecology and the Environment 5(4):W1-W4.

European Environment Agency (EEA). 1998. Europe's environment: The second assessment. State of the Environment Report No. 2. Luxembourg: Office for Publications of the European Communities. http://reports.eea.europa.eu/92-828-3351-8/en.

Miles, L., A.C. Newton, R. DeFries, C. Ravilious, I. May, S. Blyth, V. Kapos and J. Gordon. 2006. A global overview of the conservation status of tropical dry forests. Journal of Biogeography 33:491-505.

Newton, A.C. 2007. Biodiversity Loss and Conservation in Fragmented Forest Landscapes: The Forests of Montane Mexico and Temperate South America. Oxford, UK: CABI.

Richter, M. 2000. The ecological crisis in Chiapas: A case study from Central America. Mountain Research and Development 20:332-339.

United Nations Development Programme (UNDP). 2004. Examples of the Successful Conservation and Sustainable Use of Dryland Biodiversity. Sharing Innovative Experiences, Vol. 9. New York: UNDP.

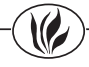

\section{Unmanned Aircraft Systems (UASs) for Ecological Research and Natural-Resource Monitoring (Florida)}

Adam C. Watts (Florida Cooperative Fish and Wildlife Research Unit, PO Box 110485, University of Florida, Gainesville, FL 32611, 352/846-0638, Fax: 352/846-0841, acwatts@ufl.edu),W. ScottBowman (Dept of Mechanical and Aerospace Engineering, University of Florida, Gainesville), Amr H. Abd-Elrahman (Geomatics Program, University of
Florida, Gainesville), Ahmed Mohamed (Geomatics Program, University of Florida, Gainesville), Benjamin E. Wilkinson (Geomatics Program, University of Florida, Gainesville), John Perry (Geomatics Program, University of Florida, Gainesville), Youssef O. Kaddoura (Geomatics Program, University of Florida, Gainesville) and Kyuho Lee (Department of Mechanical and Aerospace Engineering, University of Florida, Gainesville)

The unmanned aircraft system (UAS), also known as unmanned aerial vehicle (UAV) system, is emerging as an important new tool for remote observation, ecological research, and natural resource monitoring. These systems offer the ability to measure biomass, plant cover, animal populations, and hydrological attributes of large areas rapidly, and with great precision and accuracy. A UAS can be used in areas that are difficult or dangerous to enter, or to monitor phenomena for which an intermediate perspective between high-altitude aerial or satellite imaging and ground-based data collection is desirable. The increasing availability of small, lightweight sensors has enabled users to mount visible-spectrum, near- and thermal-infrared, and even hyperspectral and LiDAR sensors aboard UAS.

A decade ago, faculty and students from University of Florida's departments of mechanical and aerospace engineering, geomatics, and wildlife ecology began investigating UASs for natural-resource monitoring and ecological research applications. Our criteria for the ideal UAV were that it would need to be hand-launched and operable by one or two people not trained as pilots (for example, a pair of field biologists possessing some UAS training). In addition, the ideal UAV would have the capability for autonomous operation using a computer autopilot, and imagery geo-referencing capability. Because of the requirements for hand-launch, easy transportation, and a desire to mitigate the risks from a potential crash, we chose to focus on so-called small UAVs, which tend to have wingspans under three meters and weights below $10 \mathrm{~kg}$. Currently, UASs range in size from the U.S. Air Force's RQ-4B Global Hawk, with a 3.3 wingspan and 40 flight duration, to micro air vehicles (MAVs) with wingspans of centimeters and the ability to fly indoors.

Experience with then-available UASs (Jones 2003, Jones et al. 2006), and a continuing survey of the marketplace, have revealed some generalities about commercially available UASs. First, military applications drive UAS development. UASs, therefore, tend to carry sensors optimized for military surveillance rather than biological surveys, and only the larger UASs - which offer fewer advantages comparable to manned aircraft-are equipped with payloads that collect meaningful information for the naturalresource user. Also, UASs remain prohibitively expensive for most agencies and organizations.

These realities led our group to explore the development of our own UAS in collaboration with the University of 
Florida's Micro Air Vehicle Laboratory (Lee 2004). The resulting family of systems includes a UAV constructed of composite materials such as carbon fiber, fiberglass, and aramid fiber, providing the ability to land the UAV in rough areas without damage to the craft or its payload. The craft can be easily disassembled and placed in boxes for transportation in vehicles or even aboard commercial airliners. The UAV is powered by an electric motor and rechargeable batteries, making it more reliable, safer, and quieter than $U A V$ s powered by gasoline or nitromethane. A GPS-guided autopilot enables autonomous navigation and the ability to fly over a designated area repeatedly and with great accuracy. Recording and transmission of position and attitude data of the UAV enables photogrammetric adjustments to be made to collected imagery, allowing for the orthorectification and spatial analysis of collected photos (Wilkinson 2007). Imagery can be further analyzed using computer programs to automatically detect and quantify objects such as birds (Abd-Elrahman et al. 2005). Payloads have included visible-spectrum video, still cameras, and a thermal-infrared sensor, for research applications ranging from manatee surveys to monitoring of levees for leaks (Figure 1).

A small but growing number of companies manufacture small to medium UASs suitable for non-military applications. These aircraft have been used to collect valuable data on the absorption of sunlight by atmospheric aerosols, for example (Ramana et al. 2006). UASs are expected to become valuable tools for research in the Arctic, where they mitigate many of the safety concerns for manned flight in remote areas or over polar waters. Larger UASs, such as civilian versions of the RQ-4 Global Hawk and RQ/ MQ-1 Predator, are now used for large-scale surveillance of western forest fires and hurricanes by the U.S. Forest Service and National Oceanographic and Atmospheric Administration.

Industry and academia have only begun to explore UASs as platforms from which to monitor environmental attributes and ecological phenomena. As new applications continue to arise, UASs are likely to revolutionize the methods employed in our discipline in the same ways that GIS has changed the natural sciences. With respect to this technology and the promise it offers for improvements to safety, efficiency, and scientific advancement, perhaps we will even be forgiven for saying that the sky is the limit.

\section{References}

Abd-Elrahman, A.H., L.G. Pearlstine and H.F. Percival. 2005. Development of pattern recognition algorithm for automatic bird detection from unmanned aerial vehicle imagery. Surveying and Land Information Science 65:37-45.

Jones, G.P. 2003. The feasibility of using small unmanned aerial vehicles for wildlife research. M.S. thesis, University of Florida.

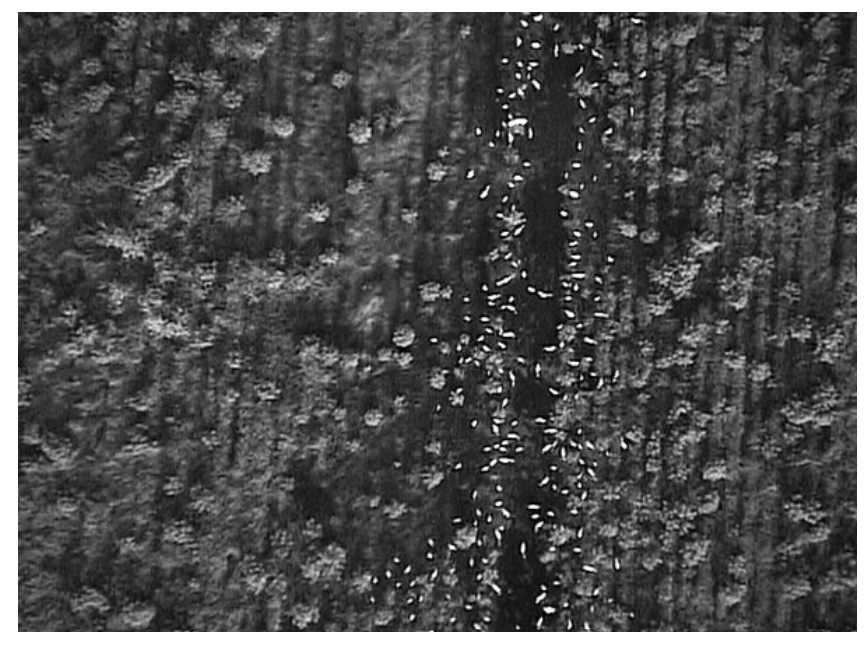

Figure 1. This low-resolution image from a UAV-mounted CCD camera shows white wading birds congregating around a drainage canal in a wildlife management area. This image was used in conjunction with image-recognition software to automatically estimate the number of birds in the image, foreshadowing a new tool to rapidly survey wildlife populations. Photo courtesy of University of Florida

Jones, G.P., L.G. Pearlstine and H. F. Percival. 2006. An assessment of small unmanned aerial vehicles for wildlife research. Wildlife Society Bulletin 34:750-758.

Lee. K. 2004. Development of unmanned aerial vehicle (UAV) for wildlife surveillance. M.S. thesis, University of Florida.

Ramana, M.V., V. Ramanathan, C.E. Corrigan, D. Kim, G. Roberts and H. Nguyen. 2006. Direct measurements of albedo and solar absorption over the Northern Indian Ocean with a new observing system of stacked multiple AUAVs. EOS Transactions, America Geophysical Union 87(52) Fall Meeting Supplement, Abstract A13B-0921. http://www-abc-asia.ucsd.edu/MAC/ RamanaAGU2006.pdf.

Wilkinson, B.E. 2007. The design of georeferencing techniques for an unmanned autonomous aerial vehicle for use with wildlife inventory surveys: A case study of the National Bison Range, Montana. M.S. thesis, University of Florida.

\section{Estimating Population Size of Mexican Wolves Noninvasively (Arizona)}

C.A. Cariappa (Dept of Natural Resources Management, Texas Tech University, Mail Stop 42125, Lubbock, TX 79409-2125,806/742-4732, chip.cariappa@ttu.edu), Warren Ballard (Dept of Natural Resources Management, Texas Tech University), Stewart Breck (National Wildlife Research Center, Fort Collins, CO), Antoinette J. Piaggio (National Wildlife Research Center, Fort Collins, CO) and Melissa Neubaum (National Wildlife Research Center, Fort Collins, CO)

Monitoring wolf abundance is a significant problem confronting biologists coordinating the recovery of the Mexican wolf (Canis lupus baileyi) population in the Blue 


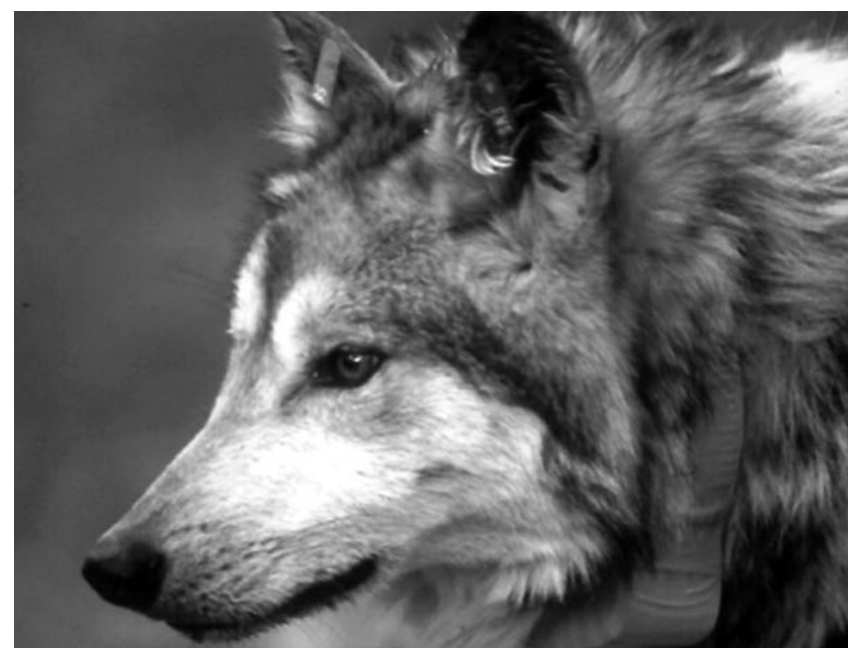

Figure 1. A female Mexican wolf (Canis lupus baileyi) from the population in the Blue Range Wolf Recovery Area in Arizona and New Mexico. Researchers use radiotelemetry to monitor noninvasively. Photo courtesy of USFWS

Range Wolf Recovery Area (BRWRA) in Arizona and New Mexico (Figure 1). Thus far, radiotelemetry has been a satisfactory method. However, collaring and tracking more wolves in the expanding population is expensive. The development of a cost-effective method to estimate Mexican wolf populations will assist the long-term management and recovery of wolves.

We are attempting species and individual identification using DNA extracted from wolf scat because scat is both readily available and easy to collect (Putman 1984). Progress in contemporary molecular genetics has made noninvasive genetic sampling of an animal population possible (Goossens et al. 2000, Prugh et al. 2005). The ability to identify an individual through DNA amplification of a scat sample allows us to treat reoccurrences of a genotype in additional samples as marked recaptures. Mark-recapture models may then be used to estimate population size based on collected genotypes. We are currently developing appropriate laboratory, sampling, and field protocols to collect scat and conduct a genetic mark-recapture study of Mexican wolves in a portion of the BRWRA.

We tested our ability to identify individual Mexican wolves in the lab by collecting scat and blood from eight captive wolves at the Sevilleta National Wildlife Refuge in New Mexico. We stored scat samples in 50-ml centrifuge tubes along with silica beads to act as a desiccant (1:4 scat to silica beads by volume), using filter paper barriers to prevent silica dust from embedding itself on the surface of the scat. We extracted DNA from surface scrapings of scat following the protocol for human DNA analysis from stool samples (QIAGEN 2007). We have successfully amplified 10 canid specific microsatellite markers (Ostrander et al. 1993) in the Sevilleta samples. These markers allowed us to obtain individual genotypes for all eight wolves. We are in the process of cross-checking genotypes obtained from scat against those obtained from blood.

We have demarcated a compact study area within the BRWRA comprising approximately $2,500 \mathrm{~km}^{2}$ in the Apache Sitgreaves National Forest in Arizona. The Interagency Field Team, which coordinates the recovery project, is using radiotelemetry to monitor wolves in the study area and knows precisely how many wolves exist there. The study area is occupied by four packs (Paradise, Hawk's Nest, Bluestem, and Rim) whose territories are contiguous with each other. Furthermore, there are no unoccupied regions within the study area that could be colonized during the duration of the study. Therefore, this study area presents us with an opportunity to use radiotelemetry estimates as a baseline to evaluate the precision and accuracy of our technique.

Wolves are known to travel along existing roads, trails, and waterways and often deposit scat along these pathways (Mech 1970). Consequently, we have laid out eight approximately $60-\mathrm{km}$ transects, some of which intersect two or three pack territories, along Forest Service roads in the study area. The total length of all transects is approximately $500 \mathrm{~km}$. All transects are navigable by four-wheel drive, high-clearance vehicles. After first clearing all transects of scat, teams of two volunteers in vehicles driven at speeds not exceeding $20 \mathrm{~km} / \mathrm{h}$ surveyed these transects on two consecutive weekends in September 2007 and collected all observed canid scats-a total of 52 samples. These transects will be surveyed again in a similar manner for three consecutive weekends in November 2007, February 2008, and April 2008.

We will use mark-recapture modeling to analyze the encounter histories generated by genotyping collected scat. However, two of the four packs are known to occupy territory outside the study area. Thus some wolves are likely to have a much higher capture probability than others, leading to low-biased population estimates under the usual model assumption that all animals have an equal probability of capture. We will attempt to overcome this difficulty by logging the distance between scat location and the edge of the study area. We will use this individual covariate to explain the variation in capture rates between individuals. The primary collection events will be modeled using a Hugginstype population estimation model (Huggins 1989), which allows for individual covariates such as average distance to the edge of the study area. The data will be analyzed using the robust design in Program MARK (White and Burnham 1999) that allows for the trading of information between primary capture periods and simultaneously allows us to estimate survival rates. We will evaluate the effectiveness of our method by determining if the confidence interval for estimated population size contains the actual population size in each sampling period. 


\section{References}

Goossens, B., L. Chikhi, S.S. Utami, J. Ruiter and M.W. Bruford. 2000. A multi-samples, multi-extracts approach for microsatellite analysis of faecal samples in an arboreal ape. Conservation Genetics 1:157-162.

Huggins, R.M. 1989. On the statistical analysis of capture experiments. Biometrika 76:133-140.

Mech, L.D. 1970. The Wolf: The Ecology and Behavior of an Endangered Species. Garden City, NJ: Natural History Press.

Ostrander, E.A., G.F. Sprague and J. Rine. 1993. Identification and characterization of dinucleotide repeat (CA)n markers for genetic mapping in dog. Genomics 16:207-13.

Prugh, L.R., C.E. Ritland, S.M. Arthur and C.J. Krebs. 2005. Monitoring coyote population dynamics by genotyping faeces. Molecular Ecology 14:1585-1596.

Putman, R.J. 1984. Facts from faeces. Mammal Review 14:79-97. QIAGEN, Inc. 2007. QIAamp DNA Stool Handbook: For DNA Purification from Stool Samples, 2nd edition. Valencia, CA: QIAGEN, Inc.

White, G.C. and K.P. Burnham. 1999. Program MARK: Survival estimation from populations of marked animals. Bird Study Supplement 46:120-138.

\section{Control of Maidenhair Vine (Mueblenbeckia complexa) (California)} Tania Pollak (Natural Resources Planner, Presidio Trust, 34 Graham St, San Francisco, CA 94129, 415/561-2733, tpollak@presidiotrust.gov)

A native of New Zealand that grows both as a shrub and by winding around other plants, maidenhair vine (Mueblenbeckia complexa) has become naturalized along parts of California's northern coast, including San Francisco Bay (NatureServe 2007). In the city of San Francisco, maidenhair vine has invaded and become dominant in several natural areas in the Presidio, part of the larger Golden Gate National Recreation Area. Local staff observed maidenhair vine in several locations in the early 1990s. In 1994 and 1995, in an attempt to control the invasive plant, the San Francisco Conservation Corps brush-cut one area of the Presidio. Without further treatments or monitoring, maidenhair vine reestablished itself throughout the site and by 2004 again dominated the area.

To evaluate maidenhair vine control treatments and inform future removal and restoration projects, I conducted an experiment at the previously brush-cut site. The site, approximately $30.5 \mathrm{~m} \times 30.5 \mathrm{~m}$, is at the headwaters of a small creek in the northwest section of the Presidio. Maidenhair vine covered an estimated 78 percent of the site, forming large hummocks over the landscape, covering other vegetation, and growing up the trunks of trees (Figure 1). Hummocks grew to approximately $1.5 \mathrm{~m}$ in height, likely on top of other vegetation. Other vegetation

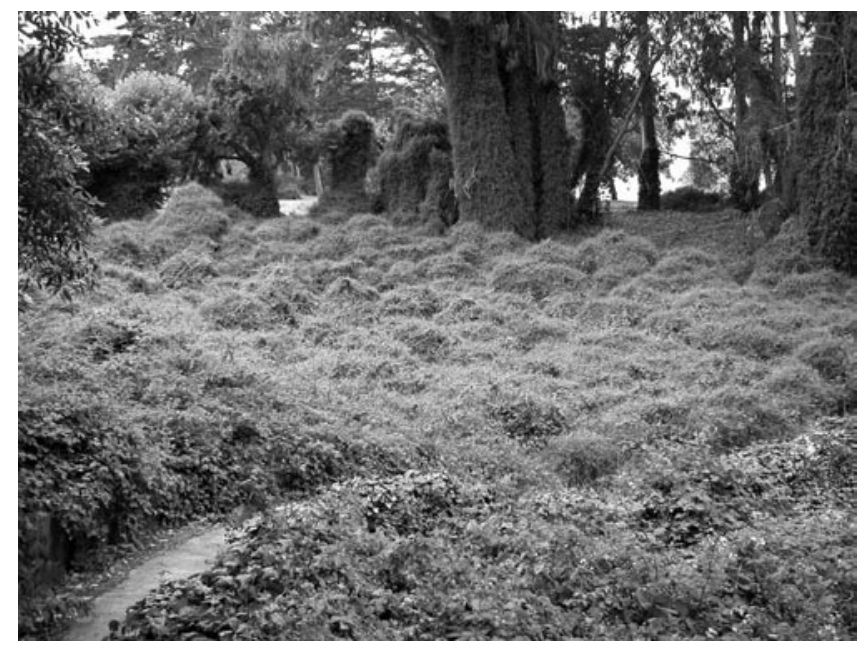

Figure 1. Project site in July 2004, prior to vegetation removal (left of path). Maidenhair vine (Muehlenbeckia complexa) dominates, forming hummocks over other vegetation and climbing tree trunks. Photos by Tania Pollak

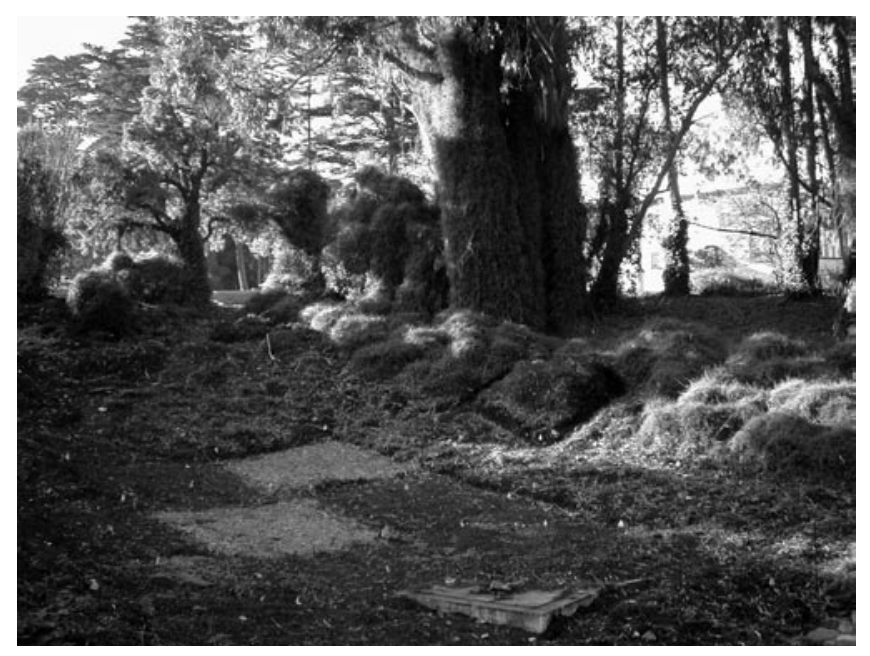

Figure 2. Project site in December 2004 after vegetation removal and experimental treatments. Foliar spray plot is visible below and slightly to the right of the large trees. Two plots covered with woodchips on top of fabric are also visible in lower portion of photo. Macerate, clip, and control plots are adjacent to the fabric plots.

visible on the site was limited to ivy (Hedera spp.) and Himalayan blackberry (Rubus discolor). Large eucalyptus and other landscape trees surrounded the site.

I compared six treatments: 1) cutting stems to a few centimeters above ground (clip); 2) cutting to short stems and mashing stem tips with brush cutters (macerate); 3) removing all vegetation to bare soil (scrape); 4) covering vegetation with landscape fabric (fabric); 5) applying glyphosate in the form of $2 \%$ Rodeo (foliar spray); and 6) initial vegetation clearing only (control). Because little is known about effective removal of maidenhair vine, most methods were designed to treat individual stems of the plant.

In September 2004 contractors prepared the experimental site by removing the majority of vegetation. Chainsaws were the most effective method for vegetation clearing, 
although chains needed frequent adjustment or changing because of challenges cutting the vine. The cut vines were removed using pitchforks and tarps (May and Associates 2004). After clearing, approximately $15-30 \mathrm{~cm}$ of duff and dense vegetation remained, revealing that maidenhair vine frequently rooted from multiple nodes over large lengths of stem. Ten $3.6 \mathrm{~m} \times 3.6 \mathrm{~m}$ plots were established within the cleared area (Figure 2); in addition, two plots were located in adjacent vegetation. A 0.6 -m wide bare earth buffer surrounded each of the 12 plots to reduce edge effect.

In the eight cleared plots assigned to clip, macerate, fabric, and control treatments, contractors removed the remaining vegetation structure and duff, being careful to leave maidenhair vine stems. Contractors raked away all remaining vegetation and duff in the two plots receiving the scrape treatment without specifically attempting to retain maidenhair vine stems. The two uncleared plots were assigned to foliar spray. All treatments were completed in October 2004.

During post-treatment monitoring, I collected data for percent cover, total number of maidenhair vine stems, and number of live stems (indicated by green leaves on stems). I could not feasibly count stems in foliar spray plots because of the dense vegetation. I collected data immediately after treatments, one month later, and approximately every two months thereafter for a total of one year. I removed fabric from one plot 12 months after installation and collected data immediately after removal, six months later, and one year after removal. I used the nonparametric median test to compare 2004 and 2005 results across all treatments.

All treatments resulted in a decline of maidenhair vine (Table 1). Immediately after treatments, percent cover of live maidenhair vine ranged from 0 to $0.5 \%$; the number of live stems was $0-1.61 \%$ of total stems, with foliar spray plots having the highest cover and control plots having the highest percentage of live stems. One year after treatment, percent cover of live maidenhair vine did not change significantly $(p=0.716)$ and ranged from 0 to $5.56 \%$, with the greatest increase in the foliar spray plots. Maidenhair vine remained at zero percent live cover in the scrape treatment. Percentage of live stems also showed little change ( $p=0.778)$ and ranged from 0 to $1.28 \%$, with the highest density continuing in control plots. Fabric treatment resulted in elimination of maidenhair vine as measured by both live stems and percent cover.

The level of effort differed among treatments, and may be an important factor in treating other populations. Overall, vegetation removal was significantly more labor-intensive than anticipated. Consultants originally estimated 110 hours for vegetation removal and treatment applications (May and Associates 2004). Initial vegetation removal required 95 hours, with an additional 91 hours to remove remaining vegetation structure and duff and apply treatments to plots. Attempting to retain stems of maidenhair
Table 1. Percent live cover and number of live stems as percentage of total stems for maidenhair vine (Muehlenbeckia complexa) in plots measured in October immediately after treatment and one year later. Data from one fabric plot was collected in October 2005, immediately after the landscape fabric was removed, and one year later in 2006.

\begin{tabular}{lllll}
\hline & \multicolumn{2}{c}{ \% Live Cover } & \multicolumn{2}{c}{ \% Live Stems } \\
Treatment & $\mathbf{2 0 0 4}$ & $\mathbf{2 0 0 5}$ & $\mathbf{2 0 0 4}$ & $\mathbf{2 0 0 5}$ \\
\hline Clip & 0.44 & 0.06 & 1.25 & 0.94 \\
Macerate & 0 & 0.125 & 0.23 & 0.23 \\
Scrape & 0 & 0 & 0.31 & 0.31 \\
Control & 0.31 & 0.375 & 1.61 & 1.28 \\
Fabric & 0 & 0 & 0 & 0 \\
Foliar Spray & 0.50 & 5.56 & $\mathrm{NA}$ & $\mathrm{NA}$ \\
\hline
\end{tabular}

vine for the clip, macerate, fabric, and control was timeconsuming, so we added the scrape plots to the study as a potentially more feasible method. Scraping to bare soil required approximately half the time than vegetation removal in other plots.

The fabric treatment appears to be the most effective treatment applied. However, subsequent removal of the fabric requires additional labor. Although the scrape treatment showed a small number of live maidenhair vine stems at the end of monitoring, the time involved for site preparation was substantially less than the other treatments. Overall, the low amount of regrowth may warrant use of this method, but followup treatments may be needed to prevent future spread. If successful, this method could save significant time and money.

Future trials should evaluate the effectiveness of treatments without the intensive duff removal, particularly landscape fabric and scraping. Moreover, a comparison is needed between foliar spraying and applying herbicide to stumps after initial vegetation removal. However, the high success rates of the fabric, macerate, and scrape treatments may not warrant use of herbicide treatments.

Although maidenhair vine cover remained low, other vegetation grew rapidly in the project site, including Himalayan blackberry (Rubus discolor), wild radish (Raphanus raphanistrum), nightshade (Solanum spp.), stinging nettle (Urtica dioica), and a variety of grasses. A flush of weeds is not unexpected after extensive vegetation removal, particularly given the large potential seed bank adjacent to the project site and in the Presidio as a whole. Several native species also grew: California blackberry ( $R$. ursinus), wild cucumber (Marah macrocarpus), and monkey seep (Mimulus guttatus). Vegetation other than maidenhair vine comprised $11.5 \%$ (fabric treatment) to $37.8 \%$ (control treatment) of cover at the end of monitoring. Regardless of removal methods, the extensive weed growth observed suggests that additional vegetation management or replanting with desired species is necessary. 


\section{Acknowledgments}

I would like to thank Jennifer Zarnoch for oversight of vegetation removal and plot treatments and Kristen Ward for her support and assistance.

\section{References}

May and Associates, Inc. 2004. Mattress wire weed adaptive management control study. Report prepared for the Presidio Trust.

NatureServe. 2007. NatureServe explorer: An online encyclopedia. Version 6.2. NatureServe, Arlington, VA. http://www. natureserve.org/explorer.

\section{(1)}

\section{An Evaluation of Engaging Volunteers to Restore Bottomland Forest (North Central Texas)}

William Forbes (Stephen F. Austin State University, Box 13047 SFA Station, Nacogdoches, TX 75962, forbesw@ sfasu.edu), Margaret Forbes (Baylor University), Kevin Stevens, Kenneth L. Dickson (University of North Texas) and Sonny Solis (Texas Parks and Wildlife Department)

The value of using volunteers in restoring and monitoring environmental resources has been widely documented (Bonney 2002, Bonney and Dhondt 1997, Noss 2002, Prysby 2002, Trumbull et al. 2000). Jordan (2003) suggests that citizen "performance" of restoration is often underappreciated, and in cases surpasses the value of habitat enhancement. Gunn (1998) and McHarg (1969) strongly emphasize the value of integrating urban residents with nature.

We report here on a project testing an alternative to standard contracting of restoration services. Our premise is that residents involved in restoration feel more connected to the local nature reserve and possibly even provide better results than the contracted work because they feel more ownership in the restoration process.

Bottomland forest in Texas has been reduced to approximately one-third of its pre-settlement distribution (Frye and Curtis 1990). The U.S. Army Corps of Engineers (ACE) is restoring bottomland forest as part of a "Section 1135, Environmental Restoration" project designed to mitigate effects of dam-building in the region. ACE worked in partnership with the City of Denton and the University of North Texas to plan a restoration project on land between Lake Ray Roberts and Lake Lewisville, which serves as a wildlife habitat corridor between the two lakes. The city's matching project funds went to the university to organize volunteers in reforesting approximately 40 ha on the west side of the Elm Fork of the Trinity River between 1999 and 2004. Volunteers also installed approximately 50 wood duck boxes and planted a variety of native wetland vegetation at one of two constructed wetlands. Volunteers were also organized to monitor reforestation survival and utilization of the wood duck nest boxes.

Two groups of volunteers were surveyed regarding their perceptions of the restoration project, environmental ethics, and the local greenbelt area. One volunteer group consisted of over 300 University of North Texas students organized for Make a Difference Day in October 2001. A second group consisted of 20 individuals, including local residents and University of North Texas students and faculty organized on September 2001 to commemorate a local Earth Charter Community Summit. We received 200 responses to our survey, 185 of which were from a cross section of students participating to fulfill community service commitments and not especially drawn towards environmental activities. Questions sought to determine how many times they had visited the area, whether they were aware of the area as part of an interconnected network of green space, how rewarding they found the experience, and whether the experience increased their environmental concern.

Questionnaire results revealed that $85 \%$ of those surveyed were visiting the area for the first time and only 42 people $(21 \%)$ were aware the area was part of an interconnected network of natural green space. Almost $60 \%$ thought the experience was very rewarding, however, and $38 \%$ thought the experience was somewhat rewarding. In addition over half $(54 \%)$ thought the work definitely increased their environmental concern, and 33\% thought the work somewhat increased their environmental concern.

These survey results support the premise that restoration work increased residents' connection to the nature preserve. This connection is also indicated by the fact that the same volunteer groups (Texas Waterfowl Hunters Organization, North Central Texas College environmental biology classes, Boy Scouts, community service workers, and University of North Texas students) involved in planting and nest box installation followed up with participation in monitoring of seedling survival, nest box use, and wetland plant establishment.

In terms of the efficacy of volunteer work, seedling survival rates in the areas planted by volunteers were high for this droughty region. A comparative survey of seedling survival in a contracted reforestation area found only natural regeneration of non-planted species, such as green ash (Fraxinus pennsylvanica), despite above average precipitation during the contracted planting season (2000 to 2001). Thus, it may be that volunteers can perform higher quality restoration, especially if their efforts include monitoring and multiple plantings. In terms of the cost of volunteer labor, however, price per hectare of reforestation and nest box installation was figured at approximately twice that of contracting the services (approximately \$1,250/ha versus $\$ 625 / \mathrm{ha}$ ), mostly due to re-plantings. Multiple plantings 
by contractors to gain higher seedling stocking rates in the remote field sites, along with nest box installation and wetland plantings, may bring the costs equal to or higher than volunteer project costs. Such high costs may be necessary to reach adequate stocking of mast-producing species in this droughty landscape where survival rates are often 10 to $20 \%$ of initial plantings. The city's matching funds covered tools, seedlings, seedling protection tubes, duck box support posts, and graduate student support to organize monthly projects over three years, including two to three replantings.

Communities considering restoration projects may want to allocate funds on a portion of the project for volunteer coordination in lieu of contracting. This approach was successful in restoring bottomland forest habitat in North Central Texas. However, the extra multi-year, per hectare costs may be prohibitive on a large scale, depending on the amount of follow-up monitoring needed to meet objectives.

\section{Acknowledgments}

The City of Denton, U.S. Army Corps of Engineers, Texas Parks and Wildlife Department, and the University of North Texas Department of Philosophy and Religion Studies, Institute of Applied Sciences, School of Community Service, and Volunteer Center were instrumental in assisting with the project.

\section{References}

Bonney, R. 2002. Observations count. Wild Earth 11(3/4): $18-23$.

Bonney, R. and A.A. Dhondt. 1997. FeederWatch: An example of a student-scientist partnership. Pages 31-53 in K.C. Cohen (ed), Internet Links for Science Education: Student-Scientist Partnerships. New York: Plenum Press.

Frye, R.G. and D.A. Curtis. 1990. Texas Water and Wildlife: An Assessment of Direct Impacts to Wildlife Habitat from Future Water Development Projects. Austin, TX: Texas Parks and Wildlife Department.

Gunn, A.S. 1998. Rethinking communities: Environmental ethics in an urbanized world. Environmental Ethics 20:341-360.

Jordan, W.R., III. 2003. The Sunflower Forest: Ecological Restoration and the New Communion with Nature. Berkeley: University of California Press.

McHarg, I.L.1969. Design with Nature. Garden City, NY: Doubleday Press.

Noss, R. 2002. Citizen scientist or amateur naturalist? Wild Earth $11(3 / 4): 15-17$.

Prysby, M. 2002. A meeting of monarchs and citizens. Wild Earth 11(3/4):39-43.

Trumbull, D., R. Bonney, D. Bascom and A. Cabral. 2000. Thinking scientifically during participation in a citizen-science project. Science Education 84:265-275.

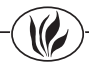

\section{Seed Bank Dynamics of Sand Pine Scrub and Longleaf Pine Flatwoods of the Gulf Coastal Plain (Florida)}

Andrew D. Ruth (School of Forest Resources and Conservation, University of Florida, Gainesville), Shibu Jose (School of Forest Resources and Conservation, University of Florida, PO Box 110410, Gainesville, FL 32611, 352/846-0872, sjose@ufl.edu) and Deborah L. Miller (Dept of Wildlife Ecology and Conservation, University of Florida, Milton)

We studied two forest associations of the southeastern Coastal Plain of the United States, mainland scrub and longleaf pine (Pinus palustris)-dominated flatwoods, and the ecotonal association separating them. Fire suppression, silvicultural activities, cattle overgrazing, and fragmentation have led to a reduction in the herbaceous component of these ecosystems in Florida and elsewhere in the southern United States. Predicting the potential rate and composition of herbaceous species recovery following reintroduction of fire requires an understanding of the sources of herbaceous recolonization, including seed banks and seed rain from nearby sites or remnant adult plants.

We addressed two questions in our study: 1) how does composition and size of seed bank vary among the three fire-suppressed communities, and 2) how does the seed bank compare to the extant vegetation in the different communities? We conducted our study during 2001 and 2002 at the 558-hectare Naval Live Oaks (NLO) area of the Gulf Islands National Seashore located in Santa Rosa County, Florida. The study sites were located in longleaf pine flatwoods, mainland scrub, and the transitional ecotone (Myers 1990). Within each vegetation type, 20 plots $(50 \mathrm{~m} \times 10 \mathrm{~m})$ were randomly established within fire-suppressed (for over 50 years) areas. The density of all woody species $<1 \mathrm{~cm}$ diameter-at-breast-height $(\mathrm{DBH})$ and individual herbaceous species cover were recorded within all plots in three $0.5-\mathrm{m}^{2}$ quadrats and data pooled for each main plot.

Soil samples were collected during July 2001 from ten randomly chosen plots from each of the communities. From each plot, four random mineral soil cores (surface area of each core was $40.7 \mathrm{~cm}^{2}$ ) were taken to a depth of 5 $\mathrm{cm}$, cold stratified $\left(8^{\circ} \mathrm{C}\right)$ for one week, placed in pots, and arranged in a randomized block design on a greenhouse mist bench with five replications. During the study period (July 2001-March 2002), pots were watered with a mist to saturation every third day. Seedling germination was recorded and specimens with inflorescences were removed, dried, and identified progressively over the nine months by a professional taxonomist. Viable seed densities (seeds/ $\mathrm{m}^{2}$ ) were calculated according to Toledo (1986). Sorenson's similarity indices were utilized to compare relationships between the seed banks and extant vegetation. 
Table 1. Number of seedlings (seeds $/ \mathrm{m}^{2}$ ) germinated from soils collected in three community types in Naval Live Oaks, Florida. Status abbreviations: $\mathrm{N}=$ native; $\mathrm{NC}=$ native characteristic; $\mathrm{NW}=$ native weedy; $\mathrm{N}-\mathrm{Wet}=$ native wetland; SC = scrub; LL = longleaf pine (Pinus ponderosa).

\begin{tabular}{|c|c|c|c|c|c|}
\hline \multirow[b]{2}{*}{ Species } & \multirow[b]{2}{*}{ Growth Habit } & \multirow[b]{2}{*}{ Status } & \multicolumn{3}{|c|}{ Community Type } \\
\hline & & & Scrub & Longleaf pine & Ecotone \\
\hline Conradina canescens & Shrub & NC-SC & 7 & 13 & 5 \\
\hline Conyza canadensis & Forb & NW & 3 & 5 & 3 \\
\hline Cyperaceae family & Sedge & NC-LL & 0 & 2 & 0 \\
\hline Cyperus retrorsus & Sedge & NC-LL & 0 & 3 & 0 \\
\hline Dichanthelium dichotomum var. dichotomum & Grass & NC-LL & 0 & 0 & 1 \\
\hline Dichanthelium strigosum var. leucoblepharis & Grass & NC-LL & 0 & 6 & 3 \\
\hline Dichanthelium spretum & Grass & NC-LL & 0 & 1 & 0 \\
\hline Dicot seedling & & & 0 & 4 & 0 \\
\hline Eleocharis microcarpa & Sedge & NC-LL & 0 & 2 & 0 \\
\hline Erigeron quercifolius & Forb & N-Wet & 0 & 0 & 1 \\
\hline Facelis retusa & Forb & NW & 0 & 1 & 0 \\
\hline Gamochaeta falcata & Forb & NW & 2 & 1 & 0 \\
\hline Gnaphalium spp. & Forb & NW & 1 & 0 & 0 \\
\hline Hypericum gentianoides & Forb & NC-LL & 0 & 2 & 0 \\
\hline Juncus spp. & Rush & $\mathrm{N}-$ Wet & 0 & 170 & 0 \\
\hline Kalmia hirsuta & Shrub & $\mathrm{N}$ & 0 & 7 & 0 \\
\hline Oxalis corniculata & Forb & NW & 0 & 0 & 1 \\
\hline Panicum spp. & Grass & NC-LL & 5 & 1 & 3 \\
\hline Poaceae family & & & 0 & 27 & 0 \\
\hline Polypremum procumbens & Forb & NW & 1 & 6 & 0 \\
\hline Xyris flabelliformis & Forb & $\mathrm{N}$ & 0 & 9 & 0 \\
\hline Xyris spp. & Forb & $\mathrm{N}$ & 0 & 1 & 0 \\
\hline Total & & & 19 & 261 & 17 \\
\hline
\end{tabular}

A total of 297 seedlings were observed. Twenty-eight taxa germinated from the seed bank: 19 were identified to species, 6 to genus, 2 to family, and 1 to seedling type (i.e., dicotyledon vs. monocotyledon). Six of these taxa occurred in the scrub, eighteen in the longleaf, and seven in the ecotone sites (Table 1). Mean viable seed densities were $0.47,0.42$, and 6.40 seedlings $/ \mathrm{m}^{2}$ for the scrub, ecotonal, and longleaf pine-dominated sites, respectively. Densities of viable seed stock within the soils of longleaf pine or scrub communities are comparatively unknown owing to the scarcity of seed bank empirical data. In a Florida longleaf pine sandhill, Lang (2002) observed 2000 seeds/ $\mathrm{m}^{2}$. Carrington (1997) found densities ranging from 0 to 772 seeds $/ \mathrm{m}^{2}$ in the soils of five long-unburned sand pine (Pinus clausa) scrub sites in Florida, with median densities ranging from 0 to 41 seeds $/ \mathrm{m}^{2}$.

Comparisons within the three fire-suppressed communities revealed essentially no resemblance between seed banks and extant vegetation (Table 2). The important grass species found in longleaf pine forest within this region and on NLO are wiregrass (Aristida stricta), panicgrass (Panicum spp.), rosette grass (Dichanthelium spp.), little bluestem (Schizachyrium scoparium), and, near wetland depressions, Florida sandreed (Calamovilfa curtissii). However, only Panicum and Dichanthelium species emerged during the greenhouse study. Several other species reported as characteristic of flatwoods (Maliakal et al. 2000) were also present: pine barren flatsedge (Cyperus retrorsus), smallfruit spikerush (Eleocharis microcarpa), thoroughwort (Eupatorium spp.), St. Johnswort (Hypericum spp.), and yelloweyed grass (Xyris spp.). Several species present were not characteristic of this community and included Canadian horseweed (Conyza canadensis), cudweed (Gnaphalium spp.), clustered mille grains (Oldenlandia uniflora), and juniper leaf (Polypremum procumbens).

The mainland scrub association is generally characterized by an overstory of sand pine, a midstory of sclerophyllous oaks (Quercus geminate, Q. myrtifolia, and $Q$. chapmanii) and palmettos (Sabal etonia, Serenoa repens), and a sparse herbaceous understory (Menges et al. 1993). Typical understory plants include sandyfield beaksedge (Rhynchospora megalocarpa), wild indigo (Baptisia spp.), sand heath (Ceratiola ericoides), and Apalachicola toadflax (Nuttallanthus floridanus) (Greenberg et al. 1995, Carrington 1997). None of these species were observed in the seed bank. However, false rosemary (Conradina canescens), a shrub found in scrub communities, was observed in the seed bank. As expected, the ecotone seed bank showed species characteristics of both scrub and longleaf pine communities.

Overall, the viable seed density of all community seed banks investigated was low compared to other studies (e.g., 
Table 2. Matrix of Sorenson's similarity coefficients based on relative frequency comparing seed bank and extant vegetation for three community types (SC: scrub, LL: longleaf pine (Pinus ponderosa), EC: ecotone) in Naval Live Oaks, Florida.

\begin{tabular}{lcccccc}
\hline & SC (seed) & LL (seed) & EC (seed) & SC (extant) & LL (extant) & EC (extant) \\
\hline SC (seed) & 1.00 & & & & & \\
LL (seed) & 0.40 & 1.00 & & & & \\
EC (seed) & 0.36 & 0.29 & 1.00 & & & \\
SC (extant) & 0.00 & 0.04 & 0.00 & 1.00 & 1.00 & \\
LL (extant) & 0.00 & 0.07 & 0.04 & 0.50 & 0.64 & 1.00 \\
EC (extant) & 0.00 & 0.10 & 0.04 & 0.63 & 0.004 \\
\hline
\end{tabular}

Lang 2002), and several of the species that germinated are considered "weedy" (i.e., disturbed site colonizers). In addition, there was little correspondence between the seed banks and extant vegetation for all communities (Table 2; see Ruth et al. 2007 for a list of extant species). The seed bank samples tended to resemble each other more than the extant vegetation of the corresponding communities.

These results indicate that the seed banks of NLO are poor sources for regeneration of typical plant communities of NLO. When the dominant or co-dominant plant species in the community do not generate a large or long-lived seed bank, ecological restoration by seedbank recruitment is not a viable option (Laughlin 2003).

Little to no information exists for the causes of seed decline and loss of viability specifically from longleaf pine flatwoods and scrub habitats. Loss of the herbaceous component owing to fire suppression in open pine communities in the southern United States is well documented. These losses result from reductions in light caused by the proliferation of taller shrubs and palmettos and from the elimination of germination microsites caused by litter layer buildup (Maliakal et al. 2000). In addition to fire suppression, grazing and logging may have eliminated herbaceous species. Many scrub herbaceous plants are gap specialists, and long periods of fire exclusion may be detrimental to their long-term abundance (Hawkes and Menges 1995). These scrub plants require open sites for seedling establishment, which disappear during long periods of fire exclusion. In addition, small herbs suffer light attenuation from the increase of taller shrubs and sand pine overstory. Fragmentation of scrub and pine flatwoods sites throughout Florida has made it more difficult for seed dispersal between habitats. All or a portion of the above reasons are potentially responsible for limiting the addition of fresh, viable seeds to the study habitats.

Restoration of the herbaceous layer of the NLO communities will require some form of disturbance, which allows for the creation of openings in the plant midstory and litter layer. Burning is often considered the most efficient of disturbance options because it can serve a variety of purposes including gap creation, short-term nutrient influx to the soil, and seed scarification. Even where burning creates opportunities for restoration, however, the depauperate seed bank offers little opportunity for seedling recruitment. Since past cultural activities have potentially degraded the herbaceous strata of NLO, recruitment from extant vegetation may also be limited. The results of our study emphasize the importance of seeding to restore the understory of long fire-suppressed longleaf pine flatwoods and sand pine scrubs at NLO and elsewhere in the southeastern Coastal Plain of the United States.

\section{References}

Carrington, M.E. 1997. Soil seed bank structure and composition in Florida sand pine scrub. American Midland Naturalist 137:39-47.

Greenburg, C.H., D.G. Neary, L.D. Harris and S.P. Linda. 1995. Vegetation recovery following high-intensity wildfire and silvicultural treatments in sand-pine scrub. American Midland Naturalist 133:149-163.

Hawkes, C.V. and E.S. Menges. 1995. Density and seed production of a Florida endemic, Polygonella basiramia, in relation to time-since-fire and open sand. American Midland Naturalist 133:138-148.

Lang, N. 2002. Soil Seed Bank Dynamics of Oak-Hickory Scrub of the Lake Wales Ridge, Florida. Lake Placid, FL: Archbold Biological Station.

Laughlin, D.C. 2003. Lack of native propagules in a Pennsylvania, USA, limestone prairie seed bank: Futile hopes for a role in ecological restoration. Natural Areas Journal 23:158-164.

Maliakal, S.K., E.S. Menges and J.S. Denslow. 2000. Community composition and regeneration of Lake Wales Ridge wiregrass flatwoods in relation to time since fire. Journal of the Torrey Botanical Society 127:125-138.

Menges, E.S., W.G. Abrahamson, K.T. Givens, N.P. Gallo and J.N. Layne. 1993. Twenty years of vegetation change in five long-unburned Florida plant communities. Journal of Vegetation Science 4:375-386.

Myers, R.L. 1990. Scrub and high pine. Pages 150-193 in R.L. Myers and J.J. Ewel (eds), Ecosystems of Florida. Orlando: University of Central Florida Press.

Ruth, A., D.L. Miller, S. Jose and A.J. Long. 2007. Effects of reintroduction of fire into fire suppressed coastal scrub and longleaf pine communities along the Lower Gulf Coastal Plain. Natural Areas Journal 27:332-344.

Toledo, M. 1986. Soil seed bank and reproductive properties of selected graminoids as influenced by microtopographic variation within a San Antonio prairie. M.S. thesis, Texas A\&M University.

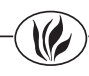

